\title{
The Logic of the Trinity
}

\author{
Einar Duenger Bohn
}

Published online: 2 August 2011

(C) The Author(s) 2011. This article is published with open access at Springerlink.com

\begin{abstract}
Roughly, the problem of the Trinity is the problem of how God can be one and yet be the Father, the Son, and the Holy Spirit, which are three, not one. That one thing is identical with three distinct things seems to violate traditional laws of identity. I propose a solution to this problem according to which it is just an ordinary claim of one-many identity. For example, one pair of shoes is identical with two shoes; and my one body is identical with its six limbs of arms, legs, head, and torso. The pair of shoes is not identical with each one of the two shoes, nor is my body identical with each one of its six limbs, but rather identical with all of them taken together, or collectively. I argue that the problem of the Trinity should be understood accordingly: God is identical with the Father, the Son, and the Holy Spirit collectively, but not with each one of them distributively. According to the way I develop this proposal, no traditional laws of identity are violated, but merely generalized in an intuitive way. I argue that this is compatible with Christian Orthodoxy as given by the Athanasian Creed. I end by responding to some anticipated objections.
\end{abstract}

\section{Keywords Trinity. Identity}

The logical problem of the Trinity threatens Christianity with incoherence. ${ }^{1}$ Many solutions have been suggested, but arguably without much removal of the threat. ${ }^{2}$ In

\footnotetext{
${ }^{1}$ I henceforth assume that a Christian strives for (at least) true belief and that truth requires coherency.

${ }^{2}$ For a survey plus references, see, e.g., Tuggy (2009) and Rea (2009). See also Brower and Rea (2005a). For a good presentation and discussion of the logical problem, see Cartwright (1987). For some fairly interesting and sophisticated, but in my mind ultimately incoherent solutions, see Geach (1967), Swinburne (1994), and Brower and Rea (2005b).
}

E. D. Bohn $(\bowtie)$

The Ethics Programme/CSMN/IFIKK, University of Oslo, Postboks 1020, Blindern, 0315 Oslo, Norway

e-mail: e.d.bohn@ifikk.uio.no 
what follows I suggest a new and independently motivated solution to it. As far as I can tell, it is a coherent one.

\section{The Logical Problem}

The logical problem is that according to Christian orthodoxy God is the Father, the Son, and the Holy Spirit, but the Father is neither the Son nor the Holy Spirit, nor is the Holy Spirit the Son. For example, according to the Athanasian Creed, which I will henceforth take as representing Christian Orthodoxy:

the Catholic faith is this: that we worship one God in Trinity, and Trinity in unity; neither confounding the persons nor dividing the substance. For there is one person of the Father, another of the Son, and another of the Holy Spirit. But the Godhead of the Father, of the Son, and of the Holy Spirit is all one, the glory equal, the majesty coeternal. Such as the Father is, such is the Son, and such is the Holy Spirit. The Father uncreated, the Son uncreated, and the Holy Spirit uncreated. The Father incomprehensible, the Son incomprehensible, and the Holy Spirit incomprehensible. The Father eternal, the Son, eternal, and the Holy Spirit eternal. And yet they are not three eternals, but one eternal. As also there are not three uncreated nor three incomprehensible, but one uncreated and one incomprehensible. So likewise the Father is almighty, the Son almighty, and the Holy Spirit almighty. And yet they are not three almighties, but one almighty. So the Father is God, the Son is God, and the Holy Spirit is God. And yet they are not three Gods, but one God. So likewise the Father is Lord, the Son is Lord, and the Holy Spirit is Lord. And yet there are not three Lords, but one Lord. For like as we are compelled by the Christian verity to acknowledge every person by himself to be God and Lord; so are we forbidden by the catholic religion to say there are three Gods or three Lords. ... And in this Trinity none is afore or after another; none is greater or less than another. But the whole three persons are coeternal, and coequal. So that in all things, as aforesaid, the Unity in Trinity and the Trinity in Unity is to be worshipped.

According to one interpretation then, Christian orthodoxy asks us to believe in the following set of propositions ${ }^{3}$ :

1. $\operatorname{God}=$ the Father

2. God $=$ the Son

3. God $=$ the Holy Spirit

4. The Father $\neq$ the Son

5. The Father $\neq$ the Holy Spirit

6. The Holy Spirit $\neq$ the Son

\footnotetext{
${ }^{3}$ This is, for example, how Brower and Rea $(2005 a, b)$ interpret the creed.
} 
But this set is inconsistent in the sense that it leads to paradox in virtue of the classical logic of identity. This logic of identity is given by the following two axioms:

7. For any $\mathrm{x}$ and $\mathrm{y}$, if $\mathrm{x}=\mathrm{y}$, then $\mathrm{x}$ and $\mathrm{y}$ share all properties

8. For any $\mathrm{x}, \mathrm{x}=\mathrm{x}$

From which we can trivially prove the following two theorems:

9. For any $x$ and $y$, if $x=y$, then $y=x$

10. For any $\mathrm{x}, \mathrm{y}$, and $\mathrm{z}$, if $\mathrm{x}=\mathrm{y}$ and $\mathrm{y}=\mathrm{z}$, then $\mathrm{x}=\mathrm{z}$

Which implies what we might call the Trinitarian Paradox: (for example) by propositions 1 and 9 it immediately follows that

11. The Father $=$ God

By propositions 11, 2, and 10 it immediately follows that

12. The Father $=$ the Son

The conjunction of propositions 12 and 4 is a direct contradiction. Q.E.D.

\section{The Solution}

With no further restrictions on our concept of God, the paradox might be taken to have the trivial polytheistic solution that there are in fact three gods, not one. But this violates the Athanasian Creed according to which we must "worship one God in Trinity and Trinity in Unity," and according to which "yet there are not three Gods, but one God." Christian orthodoxy is thus monotheistic:

\section{There is one and only one God}

Any solution to the Trinitarian Paradox must thus be compatible with 13 in order not to violate such orthodoxy.

With proposition 13 in place, we also have another paradox, which we might call the Paradox of the Cardinals: by 1-6 it follows that God is (at least) three in number, namely the Father, the Son, and the Holy Spirit, each being distinct from each other. But by 13 , God is one in number, not three. Hence, God is one in number and God is not one in number. Q.E.D.

I will now for expository reasons propose a solution to the Paradox of the Cardinals before I go on to propose a solution to the Trinitarian Paradox. I end, in the next and last section, by responding to some anticipated objections.

Consider my body. Referring to it, one might say with equal truth both that it is a body and that it is two arms, two legs, one head and a torso. In so doing one isn't referring to two distinct referents, or portions of reality, but rather to one and the same portion of reality divided up in two different ways. One such way is as one body, while the other is as two arms, two legs, one head, and a torso. Or, as Quine (1960:91) puts it with another, but similar example: 'shoes' and 'pair of shoes' range over exactly the same scattered stuff, and differ from one another solely in that they divide their reference differently. The important point for our purposes isn't exactly 
how we manage to divide one and the same portion of reality in two (or more) different ways, but rather that we in fact do so all the time. And we obviously do. For example, we say things like: The team was awesome today! They played amazingly well. And: that (one) kilometer is a thousand meters. And: my body just is those particles arranged body-wise. What's happened in such cases is that on the one hand we have referred to one thing, while in the next breath referred to that very thing as a plurality of things instead. No one should claim that in such cases we must always switch referent from first be talking about some one thing to then be talking about some many things, which aren't the same portion of reality as the one thing. That would be incredible. Rather, one should claim that what has happened is just that there is a switch between the way we thought of, or conceptualized one and the same portion of reality, not in what portion of reality we referred to. Frege (1884:59) provides another example:

While looking at one and the same external phenomenon, I can say with equal truth both "It is a copse" and "It is five trees", or both "Here are four companies" and "Here are 500 men". Now what changes here from one judgment to the other is neither any individual object, nor the whole, the agglomeration of them, but rather my terminology. But that is itself only a sign that one concept has been substituted for another. ${ }^{4}$

The implication is that numerical properties are relational properties. ${ }^{5}$ Having a certain numerical property (cardinality) depends on how it has been divided up, or conceptualized to begin with. Conceptualizing some portion of reality as two arms, two legs, one head, and a torso, it has the numerical property six holding true of it, but conceptualizing the same portion of reality as a body. it has the numerical property one holding true of it. Independently of being conceptualized it has no particular numerical property holding true of it at all.

Likewise with God: conceptualizing the portion of reality that is God as the Father, the Son, and the Holy Spirit, we have conceptualized it as being three in number, but it is nonetheless the same portion of reality as what we might conceptualize as God, and hence as being one in number. Numerical properties aren't properties holding of it independently of how it is being conceptualized. This is of course not saying that one conceptualization cannot be better somehow than another, nor that they cannot be equally good. It is only saying that, better, worse, or equal, it is a conceptualization of one and the same portion of reality either way.

\footnotetext{
$\overline{4}$ This is also, for example, how St Thomas Aquinas (1253-55/1993: 240) thinks of things: "as a single real (geometrical) point may truly correspond to several conceptions we frame of it: conceived of in itself, conceived of as a (circle's) centre, conceived of as the end of a line. All these conceptions are in the mind as subject, yet in the point itself as giving a basis to the truth of the conceptions." It is also how Descartes (1985:227) thinks of the relation between corporeal substances and regions of space: "There is no real distinction between space, or internal place, and the corporeal substance contained in it; the only difference lies in the way in which we are accustomed to conceive of them." There are plenty other examples, but the general idea should by now be clear enough.

${ }^{5}$ Frege (1884) concludes that numerical properties are second-level properties, i.e., properties of concepts, not of the "external phenomenon" falling under the concepts. For reasons I cannot go into here, I suggest instead that numerical properties are indeed first-level properties, properties of the "external phenomenon," but relational such properties, with a concept as the relational unit.
} 
This solves the Paradox of the Cardinals because it is not true that God is one in number and that God is not one in number, simpliciter. Rather, what is true is that God is one in number relative to one way of conceptualizing that portion of reality that $\mathrm{He}$ is, but not one in number relative to another way of conceptualizing it. We thus get the logical form: One $(\mathrm{x}, \mathrm{y})$ \& not-One $(\mathrm{x}, \mathrm{z})$, which is not a contradiction (where ' $x$ ' here ranges over portions of reality and ' $y$ ' and ' $z$ ' ranges over concepts).

The trick to solve the Trinitarian Paradox is now to collapse 1-3 into the following proposition:

\section{God $=$ the Father, the Son, the Holy Spirit,}

where 'God' is a singular term, and 'the Father, the Son, the Holy Spirit' is a plural term, both referring to one and the same portion of reality, albeit conceptualized differently. The further trick is to read '=' collectively, not distributively. That is, God is identical with neither the Father nor the Son nor the Holy Spirit, but rather God is identical with all of them taken together: the Father and the Son and the Holy Spirit collectively. ${ }^{6}$

An ordinary example will make the point clear. Consider three things a, b, and c surrounding one thing $\mathrm{x}$. It is then true that $\mathrm{a}, \mathrm{b}, \mathrm{c}$ taken together or collectively surround $x$, but not true that a surrounds $x$, and it is not true that $b$ surrounds $x$, and it is not true that $\mathrm{c}$ surrounds $\mathrm{x}$. To solve the Trinitarian Paradox, we simply treat identity like that; hence, the collective reading of proposition 14 .

Collapsing 1-3 into 14 is no (obvious) violation of Christian orthodoxy. First, proposition 14 is in perfect alignment with the Athanasian Creed where it demands that we worship "one God in Trinity, and Trinity in Unity; neither confounding the persons nor dividing the substance." Second, note the pattern in the creed:

Such as the Father is, such is the Son, and such is the Holy Spirit. The Father uncreated, the Son uncreated, and the Holy Spirit uncreated. The Father incomprehensible, the Son incomprehensible, and the Holy Spirit incomprehensible. The Father eternal, the Son, eternal, and the Holy Spirit eternal. And yet they are not three eternals, but one eternal. As also there are not three uncreated nor three incomprehensible, but one uncreated and one incomprehensible. So likewise the Father is almighty, the Son almighty, and the Holy Spirit almighty. And yet they are not three almighties, but one almighty. So the Father is God, the Son is God, and the Holy Spirit is God. And yet they are not three Gods, but one God.

It has the predicative form:

- The Father is $F$, the Son is $F$, and the Holy Spirit is $F$. And yet they are not three $F$, but one $F$

where F is uncreated, incomprehensible, eternal, almighty, and God, respectively. Seeing the predicative pattern in the first four cases, there is no reason to read the last case, according to which each three persons are God, as being a case of numerical identity. Following the predicative pattern, there is instead all the reason to read the last case too as being a case of the 'is' of predication, rather than the 'is' of identity. This is also the most simple and reasonable way to avoid contradicting the

\footnotetext{
${ }^{6}$ This distinction between a collective and a distributive reading of predicates is common in natural languages as well as in standard plural logic. See, e.g., Yi (2005, 2006) or McKay (2006).
} 
last sentence: "yet they are not three Gods, but one God." Or so I claim. ${ }^{7}$

My solution to the Trinitarian Paradox is thus that we should understand Christian orthodoxy as asking us to believe in the following set of propositions (among many others):

15. God $=$ the Father, the Son, the Holy Spirit

16. The Father $\neq$ the Son

17. The Father $\neq$ the Holy Spirit

18. The Holy Spirit $\neq$ the Son

Which is a consistent set of propositions in conjunction with the classical laws of identity as long as proposition $14 / 15$ is read collectively, not distributively. ${ }^{8}$ This set of propositions is a very simple and sufficiently good expression of the core demand in the Athanasian Creed, according to which we must worship Trinity in Unity and Unity in Trinity, but neither confound the persons nor divide the substance. It is also, as I have argued, compatible with the rest of the creed. This set of propositions is also consistent with monotheism, i.e., with proposition 13 according to which there is one and only one God. Of course, the Father, the Son, and the Holy Spirit are three, not one, but proposition 13 implies no denial of that fact. Orthodoxy recognizes that they are three and not confounded with each other through its acceptance of 4-6/16-18. It is when conceptualized as God that $\mathrm{He}$ is one, undivided in substance.

\section{Some Objections}

I anticipate at least six objections, but first note four general features of my solution.

First, the topics of plural identity and the nature of numerical properties are, as shown by the examples given above, general logical and metaphysical topics in their own right. My solution is therefore not motivated solely by the problem of the Trinity, and hence cannot legitimately be accused of being an objectionably ad hoc such solution. ${ }^{9}$

Second, my solution is not a version of modalism, the heretic view according to which the three persons are mere "appearances" or "modes" of the one God. According to my solution, the three persons are real divine existences in their own right.

Third, it is not a version of subordinationism, the heretical view according to which there is some sort of ordering relation among the three persons with respect to their divinity. For all my solution says, it might be the case that the Son is begotten by the Father and that the Holy Spirit proceeds from the Father and the Son, but nonetheless that each of the three persons is the same with respect to their divine features. For all my solution says, it might also be the case that there is no priority relation between God and the three persons; the one might be on a par with the three.

\footnotetext{
${ }^{7}$ Cf. the exchange between Wierenga (2004) and Brower (2004).

${ }^{8}$ That is, my account relies on the plural versions of Leibnizś Law: if $\mathrm{xx}=\mathrm{yy}$, then $\mathrm{xx}$ and yy share all properties, and Reflexivity: $\mathrm{xx}=\mathrm{xx}$, where each plural variable takes a plurality consisting of one or more things as its value. These plural versions entail the classical singular versions. For more details on the plural notion of identity, see Bohn, E. D. (manuscript submitted), On Treating Composition as Identity.

${ }^{9}$ As, for example, van Inwagen's (1995) solution arguably is.
} 
Fourth, it is neither a version of so-called Latin Trinitarianism (LT) nor so-called Social Trinitarianism (ST). ${ }^{10}$ Roughly, LT takes its starting point in the one and only God, and then tries to explain the three persons in Him, i.e., tries to explain how the one and only God is three persons. (Its main challenge is to avoid modalism, which my solution avoids.) ST on the other hand (again roughly) takes its starting point in the three persons, and then tries to explain the one and only God in them, i.e., tries to explain how they are one God. (Its main challenge is to avoid polytheism, which my solution avoids, but more on that below.) By identifying the one and only God with the three persons collectively in the way I suggested above, one neither takes its starting point in God nor in the three persons. By being identical, God and the three persons (collectively) are on a par in all senses of the term, and hence not sensibly explained in each other. It is important to note that my solution is to be understood literally: the one God is identical with the three persons (collectively), and the three persons (collectively) are identical with the one God. As shown above, this is not contradictory on the condition that numerical properties (or predications, if you prefer) are relational properties (predications). ${ }^{11}$

My solution thus also avoids more general objections to ST and LT as such. To partly support this further claim, consider some objections to both these forms of Trinitarianism put forth by Dale Tuggy. Tuggy (2003) objects that ST fails because it identifies God with a community of three divine persons, but since a community is neither a person nor divine, it turns out, according to ST, that God is neither a person nor divine. But that God is neither a person nor divine contradicts the scriptures. My solution identifies God with a portion of reality that can equally well be conceptualized as a plurality of three divine persons. There is no privileged way of conceptualizing it in terms of which we can explain the other way. Both ways are equally legitimate. But then God is not a mere "community" (or rather: plurality) as opposed to a divine person because the relevant portion of reality can equally well be conceptualized as a divine person, namely God. Recall, my solution is a claim of strict identity: God is the same portion of reality as the three persons.

As such it also avoids what Tuggy calls the Quaternity Problem, namely that according to ST there really are four divine persons, not three: the Father, the Son, the Holy Spirit, and God. ${ }^{12}$ According to Tuggy (2003:169):

The problem is this: in the New Testament, we encounter three divine and wonderful personal beings. In those pages there is no additional person called 'God' or 'the Godhead.'

But according to my solution, the divine portion of reality can be conceptualized as three persons, and as one person, but not, ontologically speaking, as four persons because the three persons together are the "fourth" person. So, to the extent that we think of four divine persons, we must be thinking of the same divine portion of reality "twice over," much like we can think of my body as both my arms, legs, head

\footnotetext{
${ }^{10}$ LT is also occasionally called Western or Psychological Trinitarianism, while ST is occasionally called Greek or Eastern Trinitarianism. See, e.g., Brower and Rea (2005a), Rea (2009), or Tuggy (2009).

${ }^{11}$ Of course, I cannot here fully defend the claim that numerical properties are relational, but see Bohn, E. D. (manuscript submitted). Note also that my solution can equally well be phrased in terms of numerical predications being relational rather than numerical properties being so relational. My solution is compatible with nominalism. 12 See also the discussion in Moreland and Craig (2003:589-591).
} 
and torso and as a body. We can do so, but it is, ontologically speaking, thinking of the same thing "twice over," and as such, for metaphysical purposes, an innocent act. So, yes, there is a sense in which there are four divine persons, but it is an ontologically innocent such sense compatible with the New Testament since the "fourth" person is the three persons collectively. ${ }^{13}$

Tuggy (2003:171-173) objects to what he calls popular LT by the fact that it identifies God with each one of the three persons (while upholding that each one of the three persons are mutually distinct), which violates the classical transitivity of identity. Obviously, by only employing a collective reading of the identity sign, my solution does not stumble over this problem (cf. proposition 14). But Tuggy (2003:173) also objects to what he calls refined LT by the fact that it denies there being a so-called absolute identity-relation of the form " $\mathrm{x}$ is the same as $\mathrm{y}$," and instead only accepts a so-called relative identity-relation of the form " $\mathrm{x}$ is the same $F$ as y," where $F$ is a count-noun. ${ }^{14}$ According to Tuggy, it is self-evident that there is an absolute identity-relation of the form " $\mathrm{x}$ is the same as $\mathrm{y}$." My solution does not deny that there is an absolute identity-relation (cf. footnote 8). According to my solution it is numerical properties that are relational, not identity. My solution is simply not one employing relative identity. ${ }^{15}$

So, from the foregoing, I conclude that my solution falls on neither side of the often-mentioned distinction between ST and LT, and as such avoids the more general objections raised against each side.

I nonetheless anticipate at least six objections.

First objection: identity is a one-one relation that anything bears to itself and to nothing else, but your account relies on identity also being a one-many/many-one relation, which is nonsense, so your solution is gibberish.

Reply: I take it that by my case above I have in fact made sense of how identity also comes in numerically hybrid forms. But if still unconvinced, then in addition to just ordinary language, pre-theoretic common sense, and all the passages mentioned above from Aquinas, Descartes, Frege, and Quine, I further refer the reader to, e.g., Plato's Theaetetus 204, Armstrong (1978:49, 1997:12\&18), Baxter (1988a, b), Lewis (1991:3.6, 1993), Sider (2007), and (Author). All have argued, pace van Inwagen (1994), that numerically hybrid identity-claims in fact make sense. Since I am confident that the reader sufficiently understands the claims by then, I do not see the need to repeat this whole defense here. ${ }^{16}$

Second objection: your account relies on the notorious thesis of Composition as Identity as it is found in Armstrong $(1978,1997)$ and Lewis (1991), but that thesis is

\footnotetext{
${ }^{13}$ And of course, in line with what I argued above, whenever the New Testament talks of any one of the Father, the Son, or the Holy Spirit as being God, we understand this as involving an 'is' of predication, not an 'is' of strict numerical identity. But I cannot go into an adequate interpretation of the New Testament here. But for interesting and related discussions, see Baber (2008), and the exchange between Tuggy (2004, 2011) and Hasker $(2010,2011)$. See also my last reply to the sixth objection discussed in Sect. 3 below. As for Tuggy's (2004) Deception Arguments I find them to be very interesting, but not to be a problem for my account as such. Rather they are everyone's problem.

${ }_{14}$ Tuggy has Geach (1967) in mind here.

15 As per Geach (1967), or as per the somewhat watered-down version of it found in, e.g., Brower and Rea (2005b). Personally, I agree with Tuggy in that Geach's solution implies the denial of something that seems self-evident, if anything is.

${ }^{16}$ Bohn, E. D. (manuscript submitted) in particular has replied to all the worries found in van Inwagen (1994).
} 
false, as shown by, e.g., van Inwagen (1994), Merricks (2003:20-28), Sider (2007), McDaniel (2008), and Cameron (2007, Forthcoming), so your account is false.

Reply: my account does not in fact rely on Composition as Identity as it is found in the works of Armstrong and Lewis, so the falsity of that thesis does not in fact entail the falsity of the present solution to the problem of the Trinity. A careful reader will have noticed that nowhere above have I used the mereological notions of composition, parthood, proper parthood, etc. I have only relied on a primitive notion of plural identity, not mereological notions. Obviously, relying on a primitive concept of identity is not thereby relying on the extremely controversial thesis of Composition as Identity. Now, personally I do believe that one can interpret the purely formal mereological notions of composition, parthood, proper parthood, etc., in terms of the above-used primitive notion of plural identity. But nothing in my present solution to the problem of the Trinity relies on this fact. ${ }^{17}$ My solution is compatible with all (substantial) talk of parthood being simply false (i.e., mereological nihilism).

Third objection: fine, so your account doesn't rely on mereological notions, but it does nonetheless imply that God is a complex substance, which is false on Christian orthodoxy, according to which God is a simple and undivided substance.

Reply: no, it implies no such thing. According to my solution, the divine portion of reality is both one God and three persons, but it is only when it is conceptualized as the latter that it is divided into three. On my account, it is thus simply false that God, so conceptualized, is three (or that the three persons, so conceptualized, are one), and hence simply false that God is divided in substance (or that the three persons are not divided into three persons). The only way we can make sense of such claims is by using the singular word (or term) 'God,' but really be thinking of it or conceptualizing it through the plural concept of the Father, the Son, and the Holy Spirit; or be using the plural word (or term) 'the Father, the Son, and the Holy Spirit,' but really be thinking of it or conceptualizing it through the singular concept of God. But in any such case God is still undivided in substance. Recall, my solution is to be taken literally: numerical properties are relational properties, so when the divine portion of reality is (correctly) conceptualized as one God, there is one substance there, not more than one (assuming the Athanasian Creed has it right, of course). Ascribing relational properties, numerical ascriptions are simply incomplete independent of or prior to their relational units being correctly in place, namely a legitimate conceptualization of the portion of reality to which the numerical property is ascribed.

That being said, I am not sure how much should be attached to the idea that God is simple because I am not sure to what extent we are capable of understanding him as being simple. Doesn't God have more than one thought, and hence in some way or other have more than one part? Doesn't God also have complex thoughts, and hence in some way or other is himself complex?

Fourth objection: fine, so your account entails that God is one in number, not three, and that the three persons are three in number, not one, but on your account we

\footnotetext{
${ }^{17}$ What's more, the version of Composition as Identity that results from the way that I personally believe we can interpret the mereological notions does not fall prey to any of the objections found in van Inwagen (1994), Merricks (2003), Sider (2007), McDaniel (2008), and Cameron (2007, Forthcoming). I cannot of course argue for this bold and general claim here, but see Bohn, E. D. (manuscript submitted).
} 
can equally well conceptualize the divine portion of reality as being $\mathrm{n}$ in number, for any number $\mathrm{n}$, which is false according to Christian orthodoxy.

Reply: no, not anything goes. Just like conceptualizing a woman as a witch does not make her into one, so conceptualizing the divine portion of reality as being $\mathrm{n}$ in number, for any number $\mathrm{n}$, does not make it into $\mathrm{n}$ things. Which conceptualizations are correct and which ones aren't is partly up to reality itself in the sense that it partly depends on its objective structure (or at least so I here assume). According to Christianity, the divine portion of reality isn t $\mathrm{n}$ things, for any number $\mathrm{n}$, so if we are to believe Christianity we must not believe that the divine portion of reality is $n$ things because then if Christianity were right, we would be wrong.

This last reply also goes to show that my solution is not committed to a form of metaphysical anti-realism. That numerical properties are relational properties with concepts as their relational units is compatible with reality having a real and objective numerical structure. It might be that some of the concepts (as opposed to others) are objectively more natural to be used to get at the "fundamental" numerical structure of reality without thereby making all other numerical concepts inapplicable. ${ }^{18}$ This of course further goes to show that metaphysical realism does not entail that numerical properties arent thus relational: even if reality has a most natural and "fundamental" numerical structure, numerical properties might still be relational. ${ }^{19}$

Fifth objection: fine, but concepts are mental entities, so your account is at least committed to reality's numerical structure, objective or not, being partly dependent on human mentality.

Reply: that depends on the metaphysical status of concepts, and their relations to human beings in particular. Since that's everyone's issue, I need take no particular stand on it here.

Sixth objection: fine then, but if you are such a metaphysical realist, what reason do we have on your account for thinking that 'God' singularly refers to an undivided substance, and not instead plurally refers to, say, the three persons of the Father, the Son, and the Holy Spirit? The former kind of singular reference is of course needed to avoid polytheism.

Reply: this brings to light an interesting issue, but is an unfair objection to my account in particular. The semantics of 'God,' 'Father,' 'Son,' and 'Holy Spirit' is everyone's issue, not mine in particular. ${ }^{20}$ My account seems compatible with whatever biblical scholars and semanticists might find out about it, as long as the numerical identity of God does not distribute across the three persons ('God' referring to each of the persons). Most importantly, my account is compatible with 'God' referring to a substance, and 'the Father,' 'the Son,' and 'the Holy Spirit' each referring to distinct divine persons.

It is worth noting at the end that my solution is even compatible with what at times seems to be indicated in the New Testament, and argued by Tuggy (2004), namely that God = the Father (or that 'God' refers to the Father, but not to the Son or

\footnotetext{
${ }^{18}$ Cf., e.g., Lewis (1986:59-69) and Sider (2009).

${ }^{19}$ In the case of God versus the three divine persons, I believe the Athanasian Creed is pretty clear on both ways being equally natural/fundamental. But let that be as it may for present purposes.

${ }^{20}$ Cf. Baber (2008).
} 
the Holy Spirit by virtue of neither one of them being the Father). If so, on my solution we get the following two propositions:

(19) God = the Father, the Son, the Holy Spirit (14/15 above)

(20) God $=$ the Father (New Thesis)

But propositions 19 and 20 are mutually compatible by simple plural logic: by 20, 19 becomes the Father = the Father, the Son, the Holy Spirit, which trivially collapses into the Father = the Son, the Holy Spirit, which if read collectively (in accordance with my suggested solution) is compatible with propositions 16-18 above (i.e., that each one of the three persons are numerically distinct). ${ }^{21}$

Acknowledgments Many thanks to Torstein Tollefsen and three anonymous referees for this journal.

Open Access This article is distributed under the terms of the Creative Commons Attribution Noncommercial License which permits any noncommercial use, distribution, and reproduction in any medium, provided the original author(s) and source are credited.

\section{References}

Aquinas, St. Thomas (1253-55/1993). Selected philosophical writings (T. McDermott, Ed.). Oxford. Armstrong, D. (1978). A Theory of universals: Universals and scientific realism vol. II. Cambridge University Press.

Armstrong, D. (1997). A world of states of affairs. Cambridge.

Baber, H. E. (2008). Trinity, filioque, and semantic ascent. Sophia, 47, 149-160.

Baxter, D. (1988a). Identity in the loose and popular sense. Mind, 97(388), 575-582. New Series.

Baxter, D. (1988b). Many-one identity. Philosophical Papers, XVII(3), 193-216.

Brower, J. E. (2004). The problem with social trinitarianism: a reply to Wierenga. Faith and Philosophy, 21, 295-303.

Brower, J. E., \& Rea, M. (2005a). Understanding the Trinity. Logos: A Journal of Catholic Thought and Culture, 8, 145-157.

Brower, J. E., \& Rea, M. (2005b). Material constitution and the trinity. Faith and Philosophy, 22, 487-505.

Cameron, R. (2007). The contingency of composition. Philosophical Studies, 136(1), 99-121.

Cameron, R. (Forthcoming). Composition as identity doesn't settle the special composition question. Philosophy and Phenomenological Research.

Cartwright, R. (1987). Philosophical essays. MIT Press.

Descartes, R. (1985). The philosophical writings of descartes vol. I. (Cottingham et al., Trans.). Cambridge.

Frege, G. (1884). The foundations of arithmetic. (J. L. Austin, Trans.). Blackwell 1980.

Geach, P. T. (1967). Identity. Review of Metaphysics, 21, 3-12.

Hasker, W. (2010). Objections to social trinitarianism. Religious Studies, 46, 421-439.

Hasker, W. (2011). Deception and the trinity: A rejoinder to Tuggy. Religious Studies, 47, 117-120.

Lewis, D. (1986). On the plurality of worlds. Blackwell.

\footnotetext{
${ }^{21}$ My solution thus rejects premise 4 of Tuggy's (2004:284) so-called direct argument against $S T: f \neq(f, s, h)$. Tuggy's rationale for it is that (1) each one of them is distinct, and that (2) it is self-evident that "no individual can be identical to the collection or mereological sum of itself and two other things." My solution accepts (1), but read premise 4 collectively rather than distributively, so no problem there. But by virtue of standard plural logic, my solution rejects (2). On my solution an individual can be identical to the collection (in my terminology: plurality) of itself and $n$ other things. For example, God is identical with itself and the three divine persons (God = God, the Father, the Son, the Holy Spirit). By standard plural logic, this trivially collapses into God = the Father, the Son, the Holy Spirit. Saying that such claims are self-evidently false, is thus saying that standard plural logic is self-evidently false. That is a very radical claim for which I believe there is no rationale.
} 
Lewis, D. (1991). Parts of classes. Blackwell.

Lewis, D. (1993). Many, but almost one. In D. Lewis (Ed.). Papers in metaphysics and epistemology. Cambridge, 1999.

McDaniel, K. (2008). Against composition as identity. Analysis, 68.2, 128-133.

McKay, T. (2006). Plural predication. Oxford.

Merricks, T. (2003). Objects and persons. Oxford.

Moreland, J. P., \& Craig, W. L. (2003). Philosophical foundations for a christian worldview. IVP Academic.

Quine, W. O. (1960). Word and object. MIT Press.

Rea, M. (2009). The Trinity. In T. P. Flint \& M. Rea (Eds.). The Oxford handbook of philosophical theology. Oxford: Oxford University Press.

Sider, T. (2007). Parthood. Philosophical Review, 116, 51-91.

Sider, T. (2009). Ontological realism. In D. Chalmers et al. (Eds.). Metametaphysics. Oxford.

Swinburne, R. (1994). The Christian God. Oxford.

Tuggy, D. (2003). The unfinished business of Trinitarian theorizing. Religious Studies, 39, 165-183.

Tuggy, D. (2004). Divine deception, identity, and social trinitarianism. Religious Studies, 40, 269-287.

Tuggy D (2009). Trinity. Stanford Encyclopedia of Philosophy.

Tuggy, D. (2011). Divine deception and monotheism: A reply to Hasker. Religious Studies, 47, $109-115$.

Van Inwagen, P. (1994). Composition as identity. In P. Van Inwagen (Ed.). Ontology, identity, and modality. Cambridge, 2001.

Van Inwagen, P. (1995). God, knowledge \& mystery. Cornell.

Wierenga, E. (2004). Trinity and polytheism. Faith and Philosophy, 21, 281-294.

Yi, Beyong-Uk. (2005). The logic and meaning of plurals. Part I. Journal of Philosophical Logic, 34, 459506.

Yi, Beyong-Uk. (2006). The logic and meaning of plurals. Part II. Journal of Philosophical Logic, 35, 239-288. 